\title{
Bilim Sanat Merkezi Matematik Öğretmenlerinin Kurdukları Geometrik İnşa Problemlerine Bilişsel Seviye Düzeyleri Açısından Ders İmecesi Çalışmalarının Etkisi
}

\section{Avni YILDIZ*, Serdal BALTACI**}

Öz: Bu çalışmada, üstün yetenekli öğrencilerin matematik derslerine giren öğretmenlerin geometrik inşa üzerine kurdukları problemleri geliştirmek için yürütülen ders imecesi çalışmalarının etkisinin TIMSS'in (Trends in International Mathematics and Science Study) bilişsel seviye düzeyleri bağlamında incelenmesi amaçlanmıştır. Özel durum çalışması yönteminin kullanıldığı araştırmanın katılımcılarını; üstün yetenekli öğrencilerin derslerine giren 3 matematik öğretmeni oluşturmaktadır. İki ders imecesi döngüsünün gerçekleştiği çalışmada veri toplama aracı olarak gözlem notları, mülakat ve öğrencilerin derste tuttukları notlar kullanılmıştır. Elde edilen veriler ise nitel veri analizi yöntemleri kullanılarak analiz edilmiştir. Araştırmanın sonucunda, ders imecesi çalışmaları öncesinde Bilim Sanat Merkezi matematik öğretmenlerinin daha çok bilme ve uygulama düzeyinde problemler kurdukları belirlenmiştir. Bu süreçte sadece bir öğretmen, anlamlandırma düzeyinde öğrencilerine soru yöneltebilmiştir. Fakat ders imecesi çalışmaları sayesinde bütün öğretmenler anlamlandırma düzeyinde problemler kurmaya başlamışlardır. $\mathrm{Bu}$ durum öğretmenlerin ders imecesi çalışmaları ile bilişsel düzey açısından farklı problem tiplerinin kurulmasının etkili yönlerini görebilmeleri ile mümkün olmuştur. O halde BİLSEM matematik öğretmenlerinin gelişimleri için benzer mesleki gelişim yaklaşımları kullanılmalıdır.

Anahtar Kelimeler: Bilim Sanat Merkezi matematik öğretmenleri, problem kurma, geometrik inşa problemleri, ders imecesi

* Yrd. Doç. Dr. Bülent Ecevit Üniversitesi, Ereğli Eğitim Fakültesi, Matematik Eğitimi ABD / E-mail: yildiz.avni@gmail.com

** Yrd. Doç. Dr. Ahi Evran Üniversitesi, Eğitim Fakültesi, Matematik Eğitimi ABD / E-mail: serdalbaltaci@gmail.com

$\begin{array}{lll}\text { Gönderim:08.08.2017 } & \text { Kabul:13.10.2017 } & \text { Yayın:30.10.2017 }\end{array}$ 


\title{
The Impact of Lesson Study Practices on Science Art Center Mathematics Teachers' Cognitive Levels in Geometrical Construction Problems
}

\begin{abstract}
This research aims to explore the effect of the lesson study practices conducted by mathematics teachers who teach gifted students to develop geometrical construction problems in terms of the Trends in International Mathematics and Science Study (TIMSS) of cognitive levels. Having used a case study method, the research was carried out with 3 mathematics teachers teaching the gifted students. With two-lesson study cycle, this research employed observation notes, interviews and students' notes as data collection tools. The data were analyzed through qualitative data analysis methods. Research results have revealed that Science Art Center mathematics teachers pose problems at the levels of recognition and applying before conducting lesson study practices. Only one teacher could address questions to the students at the level of elaborating. However, all teachers have begun to pose problems at the level of elaborating thanks to lesson study practices. This was made possible by the fact that teachers could see the effective aspects of lesson study practices and the existence of different problem types in terms of cognitive levels. Thus, similar professional development approaches should be used for the development of Science Art Center mathematics teachers.
\end{abstract}

KeyWords: Science Art Center mathematics teachers, problem posing, geometrical construction problems, lesson study 


\section{Giriş}

Ülkelerin kalkınmalarında önemli aktörlerden birileri olacak üstün yeteneklilere verilen eğitimin, günümüzde daha da önem kazandığı söylenebilir. Bu nedenle geleceğini düşünen ülkeler bu eğitime önem vermelidir. Ülkemizde de üstün yetenekli öğrencilerin eğitimi için çalışmalar gün geçtikçe artmaktadır (Aktepe ve Aktepe, 2009; Baki, Yıldız ve Baltacı, 2012; Baltaci, Yildiz ve Güven, 2014; Tertemiz, Doğan ve Karakaş, 2017). Fakat üstün yetenekli öğrencilerin eğitiminde öğretmenlere; daha çok problem çözme stratejisi gerektiren ödevlerin verilmesi, tartışmaya yönlendirme, projeler verme, öğrencileri okul içi ve dışı etkinliklere yönlendirme, velilerle olan işbirliği, ilerideki öğrenimleri için uzmanlar ile görüşmeler yapma gibi öğrencileri öğrenmeye teşvik edici büyük görevler düşmektedir (Koshy, 2002; Sisk, 1987).

Bilim ve Sanat Merkezleri (BİLSEM) öğretmenleri, üstün yetenekli öğrencilerin gelişimleri için onlara küçük gruplar şeklinde çalışmalarına imkân sağlayarak ders dış1 zamanlarda ilgi ve yeteneklerini geliştirecek şekilde çeşitli katkılarda bulunmaktadırlar (Şahin ve Şahin, 2013). Üstün yetenekli öğrencilerin öğretmenlerinin de üstün yetenekli olması gerekmeyebilir. Fakat kendi alanlarında yeterli deneyime ve bilgi birikimine sahip olması gerekmektedir (Sak, 2010). Bu sebepten dolayı da üstün yetenekli öğrencilerin öğretmenleri öğretimini şekillendirecek uygun yaklaşımlar bularak kendilerini geliştirmelidirler (Lewis, 1982). Söylenen bütün durumlar dikkate alındığında BİLSEM öğretmenlerinin mesleki gelişimlerinin devam edebilmesi için öğretmenlerin yaptıkları uygulamaları birlikte tartışabilecekleri ve kendilerindeki gelişimleri görebilecekleri bir yaklaşıma ihtiyaç duyulduğu söylenebilir. Bu bağlamda son y1llarda ülkemizde de öğretmenlerin mesleki gelişimlerinde önemli bir yaklaşım haline gelen ders imecesi (lesson study) çalışmalarının potansiyelinden yararlanılabilir. 
Ders imecesi öğretmenlerin mesleki gelişimlerinde kullanılan, işbirliği çalışmasına dayalı, Japonya kökenli bir öğretmen yetiştirme yaklaşımıdır (Bütün, 2012; Yıldız, 2013). Lewis (2002) ders imecesini planlama, uygulama, gözlem, tartışma, değerlendirme, revize etme, yeniden uygulama ve yeniden değerlendirme aşamalarını kapsayan bir model olarak ifade etmiştir. $\mathrm{Bu}$ nedenle ders imecesi; planlamanın yapıldı̆̆ı, dersin yürütüldügüü, gözlemlerin yapıldığı ve derse ilişkin düşüncelerin grupça paylaşıldığı okul tabanlı bir mesleki gelişim modelidir (Lewis, Perry, Friedkin \& Roth, 2012). Fernandez ve Yoshida (2004) da ders imecesi çalışmaları sürecinde; dersin işbirliği ile planlanması, uygulama sırasında dersi izleme, dersin tartışılması, dersi yeniden planlama (isteğe bağlı), yeni planın uygulanması (isteğe bağlı) ve yeni planın tartışılması (isteğe bağlı) gibi adımların bulunduğunu belirtmişlerdir. $\mathrm{Bu}$ adımlar ile ders imecesi çalışmaları; işbirliği ile katılımcıların isteklerini ifade edebildikleri, belli bir konu hakkında farkındalık kazandıkları ve yeteneklerini birlikte geliştirdikleri bir sistem haline gelmiştir (Senge, Cambron-McCabe, Lucas, Smith, Dutton \& Kliner, 2000). Murata (2011) öğretmenlerin bu süreçte içerik ve öğrenci düşüncelerine yönelik derin bir anlayış geliştirebileceklerini ve bu şekilde öğretimlerinin daha yararlı ve anlaşılır hale gelebileceğini belirtmiştir. Ders imecesi çalışmaları, karşılaşılabilecek bazı zorlukların en iyi nasıl aşılabileceğine yönelik firsatlar da sunmaktadır (Fernandez \& Yoshida, 2004). Bu avantajlar ders imecesi çalışmalarının hizmet içi kurslardan farkı olarak düşünülebilir. Bu bağlamda ders imecesi çalışmalarının bu potansiyelinin araştırmada, BİLSEM matematik öğretmenlerinin kurdukları geometrik inşa problemlerinin etkinliğini, TIMSS'in (Trends in International Mathematics and Science Study) bilişsel seviye düzeyleri bağlamında geliştirmek için kullanılması düşünülmüştür.

Geometrik inşa, pergel ve ölçüsüz bir cetvel kullanarak bazı geometrik şekilleri oluşturmak için gerekli standart prosedürlerdir (Lim-Teo, 1997). Euclid geometrisinin aksiyomatik yapısında geometrik inşalar önemlidir (Smart, 1993). NCTM (National Council 
of Teachers of Mathematics) (2000) geometrik inşanın, anlamlı öğrenme anlamına geldiğini vurgulamaktadır. Geometrik inşa, öğrencilerin farklı geometrik modeller arasındaki ilişkileri anlamalarına yardımcı olur ve problem çözme yeteneklerini geliştirir (Napitupulu, 2001; Posamentier, 2000). Ayrıca Karakuş (2014), bu inşaların geometrik kavramların anlaşılmasıı için önem arz ettiğini belirtmiş̧tir. Smart (1993) Euclid geometrisindeki temel inşaları; bir doğru parçasına eş doğru parçası çizme, bir doğru parçasını iki eş parçaya ayırma, bir doğruya dışındaki/üzerindeki bir noktadan dik doğru çizme, bir açıyı iki eş açıya ayırma, bir açıya eş açı çizme, bir açısı ve iki komşu kenarı verilen üçgeni çizme, üç kenarı verilen üçgeni çizme, çembere dışındaki bir noktadan teğet çizme ve bir doğruya dışındaki bir noktadan paralel doğru çizme olarak ifade etmektedir. Bu bakımdan Euclid geometrisinin daha fazla kullanıldığı geometri derslerinde öğretmenlerin, geometrik inşa üzerine etkinliklere ve problemlere yer vermelerinin önem arz ettiği söylenebilir. Üstelik bu esnada öğretmenler dinamik matematik yazılımlarının potansiyellerinden de yararlanmalıdır. Nitekim bu araştırmaya katılan bütün öğretmenler, temel düzeyde GeoGebra yazılımı kullanma becerisine sahiptir.

Keşfederek öğrenme, ispat, anlamlı öğrenme ve problem çözme gibi temel amaçlar geometrik inşa sürecinde gerçekleşebilmektedir (Karakuş, 2014). Erduran ve Yeşildere (2010) geometrik inşa çalışmalarında pergel ve ölçüsüz bir cetvel kullanarak şeklin çizilmesinin öneminden çok verilen bir probleme çözüm bulunması gerektĭgini vurgulamıştır. Ayrıca Napitupulu (2001) geometrik inşa sürecinde öğrencilerin problem çözme yeteneklerinin geliştiğini belirtmiştir. Diğer taraftan bir geometrik yapının sadece pergel ve ölçüsüz bir cetvel kullanarak inşa edilmesi sürecinde, nereden başlanması gerektiğinin ilk bakışta görülememesi gibi problemler matematiksel becerilerin kullanımını gerektirebilir (Erduran ve Yeşildere, 2010). Bu tür eksiklikler geometrik inşa çalışmalarının, problemlerin kurma 
etkinlikleri ile yaptırılması sonucunda tamamlanabilir. Bu nedenle araştırmada geometrik inşa üzerine kurulan problemlerin etkinliği artırılmaya çalışılmıştır.

Çağdaş eğitim anlayışında matematik öğretimi ve problem çözme birlikte düşünülmelidir. Başka bir deyişle nitelikli bir eğitim programıyla problem çözebilen insanlar yetiştirilmelidir. Çünkü problem çözme eğitimde başarıya ulaşmada son derece önemlidir ve bu bağlamda eğitimin her kademesinde matematik öğretiminin asıl amacı olmalıdır (Gümüş ve Umay, 2017; OCG, 2005). Diğer taraftan problem çözme ile problem kurmanın birbirine bağlı olduğu ve birbirini desteklediği yapılan çalışmalarda görülmektedir (Lowrie, 2002; Perrin, 2007; Silver \& Cai, 1993; Silver, 1994; Silver, 1995; Stoyanova, 2005). Problem kurma, yeni problemler sorma veya verilen bir problemi yeniden oluşturma olarak tanımlanmıştır (Ticha \& Hospesova, 2009). Ayrıca problem kurma çalışmalarına yer vermenin üstün yetenekli öğrencilerin eğitimine de katkı sağlayacağı yapılan çalı̧malarda önerilmektedir (Arıkan, 2014; Pelczer \& Rodriguez, 2011). Problem kurma ile birlikte, matematik ile günlük yaşam durumları arasındaki ilişki kurulması, matematiksel düşünmelerinin gelişimi (Abu-Elwan, 1999), eleştirel düşünme, iletişim kurma, sorgulama (Nixon-Ponder, 2001) gibi olumlu etkiler gerçekleşmektedir. Görüldüğü gibi çoğu araştırmacı, problem kurmanın matematikte önemli olduğunu vurgulamışlardır. Fakat öğretmenler bu etkinliklerde, kurdukları problemlerin bilişsel seviye düzeylerine de dikkat etmelidirler.

TIMSS' in 2007 yılındaki raporunda bilişsel seviye düzeylerini bilme, uygulama ve anlamlandırma olarak ifade edilmiştir. Bilme alt bileşeninde temel matematiksel kavramların özelliklerini bilme, temel işlemleri yapabilme ve matematiksel sembolleri doğru kullanabilme göstergeleri vardır. Rutin problemleri çözmek için uygun stratejinin belirlenmesi, seçilen stratejinin problemin çözümünde kullanılması ve matematiksel ifadelerin görselleştirilmesine yönelik göstergeler de uygulama alt bileşenindedir. Anlamlandırma alt bileşeninde ise 
mantıksal çıkarım yapmayı gerektiren, sıra dışı durumları kapsayan, bilişsel olarak üst seviyede olan matematiksel durumlar ve bu durumların gerekçelendirilmesi yer almaktadır (Mullis, Martin \& Foy, 2008). Özellikle Euclid geometrisindeki geometrik inşa sürecinde, geometrik yapıların kurulmasından çözülmesine kadar olan süreçte bu bileşenlerdeki göstergeler eğitimcilere yol gösterici olabilir.

Türkiye'de ilkokuldan liseye matematik öğretim programlarında (MEB 2013a; 2013b) geometrik inşa faaliyetleri mevcuttur, fakat bu faaliyetler sürecinde; araç-gereçlerin gelişigüzel, plansız olarak kullanılması, ispat yapma ile geometrik inşa sürecinin karıştırılması, bu süreçlerde öğretmenin uygun rehberlik yapamaması gibi çeşitli sorunlar ortaya çıkmaktadır (Erduran ve Yeşildere, 2010). Literatürdeki geometrik inşalar üzerine yapılan çalışmalar göz önüne alındığında, öğretmenlerin derslerinde geometrik inşa sürecini kullanımının (Erduran ve Yeşildere, 2010) ve çeşitli inşa araçlarının (pusula, cetvel, dinamik geometri yazılımı vb.) geometrik inşa sürecinde kullanımının incelendiği (Kondratieva, 2013; Kuzle, 2013; Pandiscio, 2002) görülmektedir.

Ders imecesi ile ilgili çalışmalarda ise farklı ders imecesi örneklerinin tanıtıldığı (Sarkar Arani, Keisuke \& Lassegard, 2010) ve öğretmenlerin bir araya getirilerek görüşlerinin alındığı (Saito, Harun, Kuboki \& Tachibana, 2006) görülmektedir. Bu çalışmalar ile öğretmenlerin; öğretim tekniklerinin geliştiği belirlenmiştir (Inoue, 2011; Lewis, Perry, Hurd \& O’Cannell, 2006). Fakat ülkemizde yapılan çalışmaların ise daha çok öğretmen adayları ile yürütüldüğü görülmektedir (Baki, 2012; Bütün, 2012; Güner ve Akyüz, 2017a; Güner ve Akyüz, 2017b). Baki (2012) araştırmasında, ders imecesi çalışmalarının sınıf öğretmeni adaylarının matematiği öğretme bilgilerinin gelişimine katkısını araştırmıştır. Bütün (2012) ilköğretim matematik öğretmen adaylarının alanı öğretme bilgisindeki gelişimlerine, ders imecesi çalışmalarının katkısını öğretimsel açıklamalar, öğretim yöntemleri ve inançlar boyutlarında incelemiştir. Güner ve Akyüz (2017a) yapmış olduğu çalışmalarında ders 
imecesi mesleki gelişim modelinin uygulanması kapsamında öğretmen adaylarının matematiksel düşünmelerine yönelik ne fark ettiklerini ve nasıl fark ettiklerini araştırmışlardır. Güner ve Akyüz (2017b) öğretmen adaylarına yönelik bir diğer çalışmalarında ise; ders imecesi mesleki gelişim modelinin uygulama sürecinde öğretmen adaylarının matematiksel düşünmelerini fark etme becerilerini incelemişlerdir. $\mathrm{Bu}$ nedenle araştırmada, Bilim Sanat Merkezi matematik öğretmenlerinin kurdukları geometrik inşa problemlerine ders imecesi çalışmalarının etkisini incelemek amaçlanmıştır. Kurulan problemlerdeki gelişim, yukarıda bahsedilen TIMSS'in raporundaki bilişsel seviye çerçevesine göre irdelenmiştir. Bu bağlamda araştırmanın, yapılan çalışmalar incelendiğinde orijinal olacağı ve literatüre önemli katkılar sağlayacağı söylenebilir.

\section{Yöntem}

\section{Araştırmanın Deseni}

$\mathrm{Bu}$ çalışmada kullanılan veri toplama araçlarından elde edilen veriler genelleme kaygısı olmaksızın analiz edilerek belirlenen araştırma problemi, araştırmaya dâhil olan özel bir grup için derinlemesine incelenmiştir. Bu yönüyle araştırmada, özel durum çalışması yöntemi kullanılmıştır.

\section{Araştırmanın Katılımcıları}

Araştırmanın katılımcılarını; Kırşehir Bilim Sanat Merkezi'ndeki ikisi erkek, biri bayan 3 matematik öğretmeni oluşturmaktadır. Öğretmenlerden biri yaklaşı 10 yıldır, diğer ikisi de 8 yıldır Bilim Sanat Merkezi'nde çalışmaktadır. Diğer taraftan bütün öğretmenler, temel düzeyde GeoGebra yazılımını kullanma ve etkinlik hazırlama becerilerine sahiptir. $\mathrm{Bu}$ durum araştırmacıların, daha önceki yıllarda araştırmanın katılımcılarının da dâhil olduğu matematik öğretmenlerine, hizmet içi kurs bağlamında GeoGebra kullanımına yönelik bilgiler ile etkinliklerin nasıl hazırlanabileceğine yönelik örnek uygulamalar üzerine eğitim verdikleri için söylenebilmektedir. 
Öğretmenlerin pergel, cetvel, iletki gibi araçlara ilave olarak yazılımların da potansiyellerinden yararlanarak geometrik inşa ile ilgili farklı problemler kurabilecekleri düşünülmüştür. Böylece öğretmenleri, kurdukları problemlerde kullandıkları araç gereçlerin sınırlamaması sağlanmıştır.

\section{Veri Toplama Araçları}

Veri toplama aracı olarak gözlem notları, yarı yapılandırılmış mülakatlar ve öğrencilerin derste tuttukları notlar kullanılmıştır.

Yarı yapılandırılmış mülakatlar araştırmada iki amaçla yapılmıştır. Birincisi öğretmenlerin sınıf içi uygulamalarında gözlemlenen olayları daha iyi açıklayabilmek adına bazı dersler sonunda yapılan görüşmelerdir. İkincisi ders imecesi çalışmaları sonrası öğrencilerin ders esnasında tuttukları notlardan elde edilen problemleri, her bir öğretmenin öğrencilerine nasıl yönlendirdiğine dair her öğretmenle yapılan görüşmelerdir. Böylece öğrenme ortamlarının nasıl oluşturulduğu bağlamında ayrıntılı fikirler alınarak, bu problemlerin de hangi bilişsel düzeyde kurulduğuna karar verilebilmiştir. Bütün bu süreçler esnasında mülakatlarda sorulacak soruların neler olabileceği alanında uzman matematik eğitimcileri ile tartışılmış ve gerekli revizeler yapıldıktan sonra öğretmenlere yöneltilmiştir.

Öğretmenlerle yürütülen mülakatların her biri öğretmenlerin izinleri alınarak dijital ses kayıt cihazı ile kaydedilmiştir. Yapılandırılmamış gözlem notları da ders imecesi çalışmaları öncesi araştırmacılar ve ders imecesi sürecinde uygulama esnasında öğretmenlerin hepsi tarafindan tutulmuştur.

\section{Uygulama Süreci}

Uygulama 2016-2017 eğitim öğretim yılının ikinci döneminde gerçekleşmiştir. Başlangıçta öğretmenlere geometri dersleri gözlemlenecek şeklinde bilgi verilmiştir. Sonra derslerin doğal akışını bozmamak adına her bir öğretmen ile bir süre derslere girilerek öğrencilerle vakit geçirilmiştir. Öğretmenlerin ifadeleri ve bu esnadaki gözlemlerden 
öğrencilerin GeoGebra yazılımı ile etkinlikler yapmaya alışık oldukları görülmüştür. Ardından her bir öğretmenin bir grupla ders imecesi çalışmaları öncesi, diğer grupla ise ders imecesi çalışmaları sonrası çalışması düşünüldüğünden üstün yetenekli öğrenciler gruplara ayrılmıştır. Bu esnada öğretmenlerin görüşleri doğrultusunda öğrencilerin başarıları dikkate alınmıştır.

Öğretmenlerle yapılan görüşmeler neticesinde daha önce öğrencilere anlatılmayan “Bir doğruya paralel ve dik doğruları çizer. Üçgende kenarortay, açıortay ve yüksekliği inşa eder. Yeterli sayıda elemanının ölçüleri verilen bir üçgeni çizer. Üç boyutlu cisimlerin farklı yönlerden iki boyutlu görünümlerini çizer." kazanımlarının geometrik şekil modelleri, pergel, cetvel, iletki ve GeoGebra yazılımı kullanılarak problemlerle anlatılması istenmiştir. Ders imecesi çalışmaları öncesinde her bir öğretmenin üçer ders saati gözlenmiştir. Geometrik inşa sürecinde her bir öğretmenin öğrenciyi sorularla nasıl yönlendirdiğine bakılarak öğretmenin amacı doğrultusunda problemlerin hangi bilişsel seviyeye girdiğine karar verilmiştir. Böylece her bir öğretmenin araştırılan problem bağlamında ders imecesi öncesi durumları netleştirilmiştir. Ardından ders imecesi çalışmalarına geçilmiştir.

Ders imecesi çalışmaları sırasında öğretmenleri bilgilendirmesi ve yapılacak tartışmaları şekillendirmesi düşünülen kılavuz, ilgili literatürden ve alan uzmanlarıyla yapılan görüşmeler sonucunda oluşturulmuştur. Böylece kılavuzun içerisinde; geometrik inşanın tanımı, geometrik inşa sürecinin nasıl gerçekleştiği, geometrik inşanın önemi, geometrik inşa esnasında kullanılabilecek araç, gereç ve yazılımlar, problem kurmanın tanımı, problem kurmanın önemi ve bilişsel seviyenin bilme, uygulama ve anlamlandırma bileşenlerinin özellikleri gibi konu başlıkları ve bu konu başlıklarına yönelik etkinlikler yer almaktadır.

Ders imecesi çalışmalarının bilgilendirme ve tartışma kısmı üç öğretmenle, araştırmacının da dâhil olduğu grupça gerçekleşmiştir. Planlama ve uygulama kısmını ise yalnız üç öğretmen yürütmüştür. Uygulama esnasında diğer öğretmenler de uygulamayı 
gerçekleştirecek öğretmenin dersine girmiştir. Uygulama 8. sınıf öğrencilerinin oluşturduğu sekiz kişi ile gerçekleştirilmiştir. Öğretmenlerden planlama kısmını ses kayıt cihazı ile kayıt etmeleri ve uygulama sırasında yansıtıcı gözlem notları almaları istenmiştir. Böylece ders imecesi çalışmalarının tartışma kısmı, bu notlar ve öğretmenlerin gözlemleri çerçevesinde gerçekleşmiştir. Her bir toplantı ise ders saati dışında grup üyelerinin bir araya gelmesiyle yaklaşık 45 dakika sürmüştür. Böylece iki ders imecesi döngüsü tamamlanmıştır.

Birinci ders imecesi çalışmalarının bilgilendirme kısmında öğretmenlerin kurmuş oldukları problemlerdeki eksikliklerine göre "Geometrik inşa nedir?, Geometrik inşa neden önemlidir?, Geometrik inşa esnasında kullanılabilecek araç gereçler nelerdir?, Problem kurma neden önemlidir?” gibi sorular sorularak BİLSEM öğretmenleriyle birlikte bu sorular üzerinde tartışmalar yapılmıştır. Sonra öğretmenlerin ders imecesi çalışmaları öncesi GeoGebra yazılımını kullanmayı bilmelerine rağmen kurdukları problemlerde yazılımı kullanmadıkları tespit edildiğinden bilhassa bu durum üzerinde de tartışmalar yapılmıştır. Bunun için de öğretmenlerle birlikte örnek etkinlikler oluşturulmuştur. Ardından öğretmenlerden planlama aşaması için sadece ders imecesi çalışmaları öncesi gözlemlenen kazanımlara (Bir doğruya paralel ve dik doğruları çizer. Üçgende kenarortay, açıortay ve yüksekliği inşa eder. Yeterli sayıda elemanının ölçüleri verilen bir üçgeni çizer. Üç boyutlu cisimlerin farklı yönlerden iki boyutlu görünümlerini çizer.) yönelik problem kurmaları istenmiştir. Çünkü gelişimi görebilmede başka değişkenlerin devreye girmemesi için kazanımları da kısıtlamak gerekmekteydi. $\mathrm{Bu}$ nedenle planlama aşamasında BİLSEM öğretmenleri hazırlamış oldukları problemleri tartışmış ve bu problemlerin sorulması sürecinde hangi araç gereçlerin kullanılabileceğini düşünmüşlerdir. Uygulama sürecinde bu problemler, bir öğretmen tarafindan derste sorulmuş ve bu süreçte diğer öğretmenler de derste hazır bulunmuşlardır. Bu esnada öğretmen, hazırladıkları plan çerçevesinde öğrencilerine rehberlik ederek problemlerin çözülmesini sağlamıştır. Uygulama sürecinden sonra ders 
imecesi grubuyla gözlenen durumlar ve planın etkinliği üzerine tartışılmıştır. $\mathrm{Bu}$ süreç ile birlikte birinci ders imecesi döngüsü tamamlanmıştır.

Ardından ikinci ders imecesi döngüsünde; bilgilendirme aşamasında ilk döngüde yaşanılan aksaklıkların problem kurma, geometrik inşa ve bilişsel seviye ile olan ilişkileri üzerinde durulmuştur. BİLSEM öğretmenleri planlama aşamasında kazanımları tekrar ele alarak geometrik inşaya yönelik problemler oluşturmuşlardır. Ardından daha önce uygulama yapmayan öğretmenlerden biri, daha önce oluşturulan problemleri planlama aşamasında kararlaştırılan yaklaşımla öğrencilere yöneltmiş ve bu süreçte yine diğer öğretmenler sınıfa girmişlerdir. Tartışma sırasında araştırmacılar, yapılan planın etkililiği ve öğrencilerden alınan tepkilere değinmişlerdir. Öğretmenler de kazandıkları deneyimlere göre geometrik inşaya yönelik problemlerin biraz daha düşündürücü ve daha çok araç gereç kullanımına gerek olan sorular olması gerektiğini belirtmişlerdir. Ayrıca öğretmenler, özellikle bu süreçte pergel, cetvel ve iletki dışında kâğıt katlama ve GeoGebra yazılımının kullanılmasının da etkili olacağını ifade etmişlerdir.

Ders imecesi çalışmalarından bir müddet sonra öğretmenlerden, ders imecesi çalışmaları öncesi geometrik inşa etkinlikleri yapılmayan farklı bir gruba yine aynı kazanımlara yönelik olarak geometrik inşa problemleri kurmaları ve derslerini bu şekilde yürütmeye devam etmeleri istenmiştir. Fakat bu süreçler sonunda öğretmenlerin kurdukları problemlerin etkililiği araştırmacının derse girmesi durumunda değişmemesi için derslere girip gözlem yapılmamıştır. Bunun yerine öğrencilerin ders esnasında tuttukları notlardan her bir öğretmenin geometrik inşaya yönelik hangi problemleri sordukları tespit edilmeye çalışılmıştır. Ardından tespit edilen bu problemler öğretmenlere sorularak teyit edilmiştir. Sonra öğretmenler ile bu problemler sürecinde öğrencilerin nasıl yönlendirildiğine dair konuşmalar yapılmıştır. Böylece yine her bir öğretmenin öğrenciyi sorularla nasıl yönlendirdiğine bakılarak problemlerin hangi bilişsel seviyeye girdiğine karar verilmiştir. $\mathrm{Bu}$ 
analiz TIMSS'in raporunda bilişsel seviyelere yönelik bahsedilen bilme, uygulama ve anlamlandırma alt bileşenlerinin Mullis, Martin ve Foy (2008)'un araştırmalarında yer alan tanımları sayesinde olmuştur.

\section{Verilerin Analizi}

Araştırmada toplanan veriler analiz edilmeden önce elde edilen verilerin dökümü ve kontrolü yapılmıştır. Güvenirliği sağlamak için birbirinden bağımsız olarak yapılan analizlerin bir araya getirilerek araştırmacılar tarafından ayrı ayrı tartışılmasıyla verilerin analizine son hali verilmiştir. $\mathrm{Bu}$ şekilde yapılan veri analizinin güvenirliği [Görüş birliği / (Görüş birliği + Görüş ayrılığı) x 100] formülü kullanılarak hesaplanmıştır (Miles \& Huberman, 1994). Bu süreçte Miles ve Huberman (1994)'1n formülü kullanılarak yapılan hesaplamalarda uyum oranı 0.84 olarak belirlenmiştir. Bu bağlamda veriler, nitel veri analizi yöntemleri kullanılarak analiz edilmiştir.

\section{Bulgular}

Her bir öğretmendeki gelişim, geometrik inşa üzerine kurulan problemlerin daha önce bahsedilen bilişsel seviye çerçevesine göre irdelenmesiyle ortaya çıkarılarak bu başlık altında sunulmuştur. Bu sunum esnasında araştırmacıya A, BİLSEM matematik öğretmeni 1'e B1 gibi kodlar verilmiştir.

\section{B1 Öğretmeninin Kurduğu Problemlere Ders İmecesi Çalışmalarının Etkisi}

BİLSEM matematik öğretmenlerinden B1 ders imecesi çalışmaları öncesinde geometrik inşaya yönelik 4, ders imecesi çalışmaları sonrasında ise 6 problem kurmuştur. $\mathrm{Bu}$ problemler şu şekildedir. 


\section{Tablo 1}

\section{B1 öğretmeninin kurmuş olduğu problemler}

Ders İmecesi Öncesi Kurulan Problemler

1. Aşağıda verilen üçgenlerin açıortay, kenarortay ve yüksekliklerini çiziniz.

\section{Bilme}
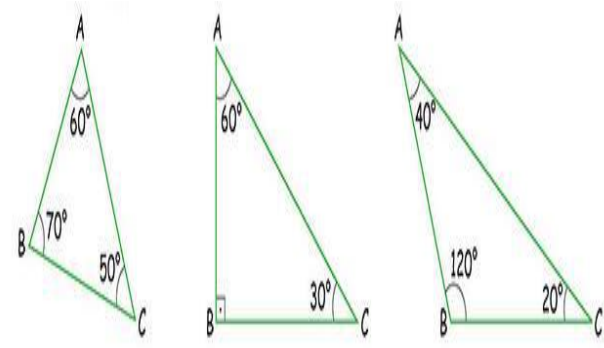

Ders İmecesi Sonrası Kurulan Problemler

1. Bir öğretmen, önceden belirlemiş olduğu bir üçgeni öğrencisine çizdirecektir. Bunun için sırasıyla aşağıdaki bilgileri öğrencisine yapmasinı söyler.

I. Bir kenarının uzunluğu $8 \mathrm{~cm}$ 'dir.

II. Bir açısının ölçüsü $40^{\circ}$ dir.

III. Bir açısının ölçüsü $80^{\circ}$ dir.

IV. Diğer açısının ölçüsü $60^{\circ}$ dir.

V. $40^{\circ}$ lik açının karşısındaki kenarın uzunluğu 10 cm'dir.

Buna göre en az kaçıncı bilgiden sonra öğrenci kesinlikle üçgeni çizebilir? Açıklayınız.

2. $B$ ir $A B C$ üçgeninin $A B$ kenarı ile $A C$ kenarının uzunluğu biliniyor. Aşağıdakilerden hangisinin de bilinmesi tek bir üçgen çizebilmek için yeterli değildir? Açıklayınız.

$\mathrm{ABC}$ üçgenin çevresi,

$\mathrm{BC}$ kenarının uzunluğu,

A açıs1

$\mathrm{B}$ açısı
Uygulama

3.

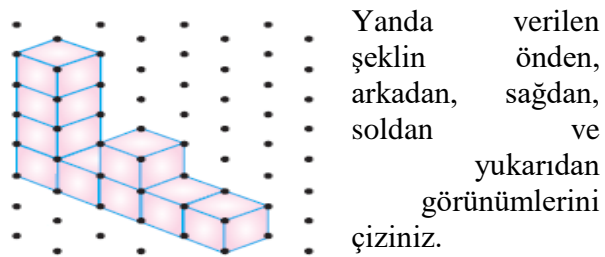
kullanarak çiziniz.
1. İki kenar uzunluğu $4 \mathrm{~cm}$ ve $5 \mathrm{~cm}$, bu iki kenar arasında oluşan açının ölçüsü $60^{\circ}$ olan bir üçgeni cetvel ve iletki kullanarak çiziniz.

2. Kenar uzunlukları $3 \mathrm{~cm}, 5 \mathrm{~cm}$ ve $6 \mathrm{~cm}$ olan bir üçgeni cetvel, pergel ve iletki araçlarını

Anlamlandirma
1. Kenarlar1 $5 \mathrm{~cm}$ ve $6 \mathrm{~cm}$ ve bu iki kenar arasındaki açı da $70^{\circ}$ olan üçgeni GeoGebra yazılımını kullanarak çiziniz.

2. Kenarları $4 \mathrm{~cm}, 5 \mathrm{~cm}$ ve $6 \mathrm{~cm}$ olan üçgeni GeoGebra yazılımını kullanarak çiziniz.

1. Diklik merkezi üçgenin köşesinde ve ikizkenarlardan birinin uzunluğu $4 \mathrm{~cm}$ olan bir üçgeni inşa ediniz.

2. GeoGebra yazılımında bir açının açıortayını sadece çember ve doğru ikonlarını kullanarak nasıl belirlersiniz? Yapınız. 
Tablo 1'de görüldüğü gibi B1 öğretmeninin kurmuş oldukları problemler TIMSS'in 2007 yılındaki bilişsel seviye düzeylerine göre incelendiğinde; ders imecesi öncesinde kurulan problemlerden birinin $(\% 25)$ bilme, üçünün (\%75) uygulama düzeyinde olduğu görülmektedir. Ders imecesi sonrasında kurulan problemlerin ise ikisinin (yaklaşık \%33) bilme, ikisinin (yaklaşık \%33) uygulama ve ikisinin (yaklaşı \%33) de anlamlandırma düzeyinde olduğu görülmektedir. Ders imecesi çalışmaları sayesinde B1 öğretmeninin bilme seviyesinde kurduğu problemlerin yüzdesinin arttı̆̆ 1 ve artık anlamlandırma seviyesinde problemler kurmaya başladığı dikkat çekmektedir.

Diğer taraftan araştırmacının gözlem notunda B1 öğretmeninin ders imecesi çalışmaları öncesi durumu aşağıdaki gibi belirtilmiştir.

B1 öğretmeninin geometrik inşaya yönelik olarak anlamlandırma seviyesinde problem kuramadığını görüyordum. Daha çok bilme ve uygulamaya yönelik problemler kurmaktaydl. Bu süreçte de özellikle bilme seviyesindeki probleminde ögrencileri kolay yönlendirmekteydi. B1 öğretmeni uygulama seviyesindeki problemlerde araç gereçleri kullandırmaya çalışıyor fakat bu süreçte pergel tutabilme, iletkiyi kullanabilme gibi bazı zorluklarla karşılaşıyordu.

Araştırmacının gözlem notundan da görüldüğü gibi B1 öğretmeni, bilme ve uygulama seviyesinde problemler kurmuş ve bazı araçların kullandırmada zorluklar yaşamıştır. Fakat B1 öğretmeninin ders imecesi çalışmaları sonrasında pergel kullanmayı bilmeyen üstün yetenekli öğrencilere, pergel kullanmalarını tekrar tekrar hatırlatması üzerine öğrencilerin pergeli daha dikkatli kullanmaya çalıştıkları görülmüştür. Bu bulguya yönelik olarak araştırmacı ile B1 öğretmeninin arasında geçen diyalog aşağıdaki gibidir.

B1: İlk başlarda her problemde pergeli kullanmayı unutmayın diye öğrencilerimi uyarmama rağmen kullanma ihtiyact hissetmiyorlardl. Ama zamanla bu çalışmalar ile daha dikkatli bir şekilde kullanmaya başladılar. 
A: Öğrencilerinizde neler değişti de pergel kullanmaya başladılar?

B1: Belki de bizden kaynaklanıyordu biz zorlamıyorduk ama bu çalışmalar ile onları pergel kullanmaya zorladık. Mesela ilk başlarda bir öğrencim hocam ben pergeli kullanmasını tam olarak bilemiyorum pergeli tutamıyorum gibi ifadeler kullanmıştı. Ama sonrasında zamanla sormuş olduğum problemlerde pergel kullanmaya çalıştı̆̆ını fark ettim.

Ayrıca ders imeceleri çalışmaları sonrasında B1 öğretmeninin, öğrencilerinden GeoGebra yazılımını kullanmalarını istediği tespit edilmiştir. Bunun için Tablo 1'den görüldügü gibi B1, anlamlandırma seviyesine uygun sorduğu problemde herhangi bir açının açıortayının, yazılım ekranında çember ve doğru ikonları kullanılarak çizilmesini istemiştir. Bu çözüm ise ancak aşağıdaki şekilde olabilir.

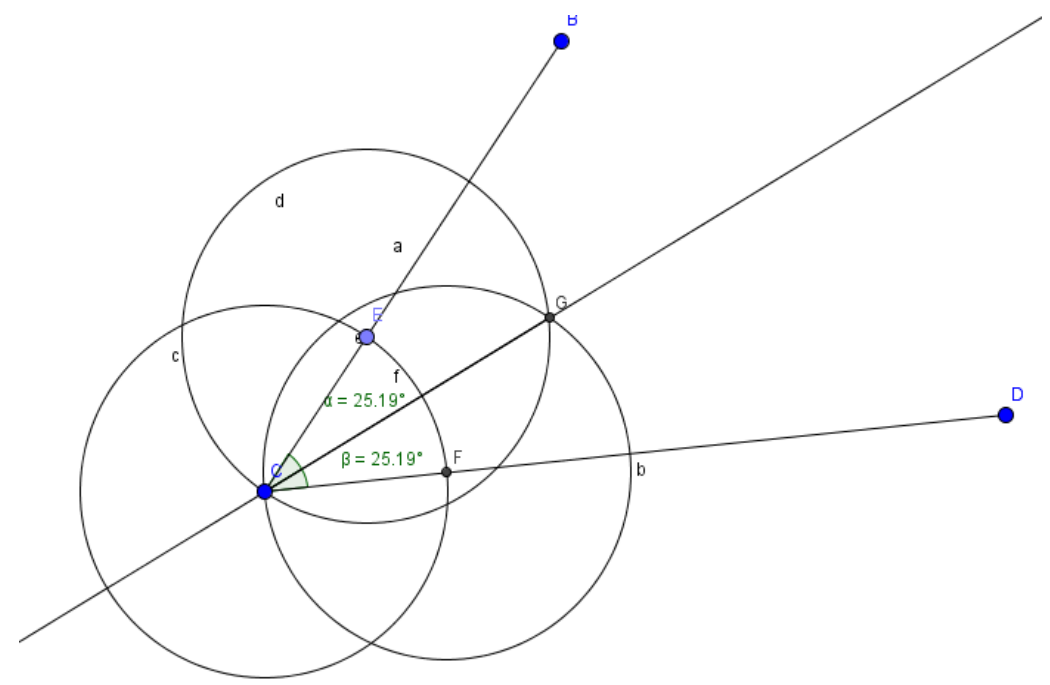

Şekil 1. GeoGebra ekranında bir açının açırtayının çember ve doğru ikonu kullanılmadan inşasına yönelik görüntü.

Diğer taraftan B1 öğretmeni ders imecesi çalışmaları hakkındaki düşüncelerini aşağıdaki cümlelerle ifade etmiştir.

B1: Bu tarz çalışmalarla birlikte çalışmak ve tartışmak çok önemli. Çünkü her tartışmamızda farklı şeyler düşünüyor ve üstün yetenekli öğrencilerin ihtiyaçlarına yönelik farklı uygulamalar gerçekleştiriyoruz. Bu şekilde de 
YYÜ Ĕ̆itim Fakültesi Dergisi (YYU Journal Of EducationFaculty),2017; 14(1):1481-1516, http://efdergi.yyu.edu.tr

http://dx.doi.org/10.23891/efdyyu.2017.53

ISSN:1305-020

kendimizi geliştirdiğimizi ve ögrencilerimize daha fazla yararlı olduğumuzu düşünüyorum.

BİLSEM matematik öğretmenlerinin ders imecesi çalışmaları sonrasında bu tür farklı olan konuları birlikte tartışmasının önemli olduğu ve bu şekilde kendilerini daha iyi geliştirmeye çalıştıkları B1 öğretmeninin yukarıdaki ifadelerinden görülmektedir.

B2 Öğretmeninin Kurduğu Problemlere Ders Imecesi Çallşmalarının Etkisi

B2 öğretmeninin hem ders imecesi çalışmaları öncesinde hem de ders imecesi çalışmaları sonrasında geometrik inşaya yönelik kurmuş oldukları problemler bilişsel seviyeye göre irdelenmiş ve aşağıdaki şekilde verilmiştir. 
Tablo 2.

\section{B2 öğretmeninin kurmuş olduğu problemler}

Ders İmecesi Öncesi Kurulan Problemler

1. A açısı $40^{\circ}, \mathrm{B}$ açısı $60^{\circ}$ ve $\mathrm{AB}$ uzunluğu 15 $\mathrm{cm}$ olan $\mathrm{ABC}$ üçgeninin tek bir şekilde çizilebilmesi için hangi iki aracı kesinlikle kullanmalısınız?

2.

Bilme

Uygulama

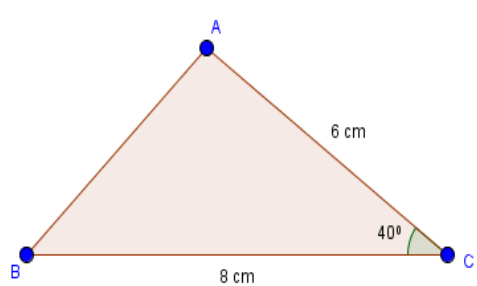

Yukarıda verilen üçgen, hangi araç-gereçlerle çizilebilir?

3.

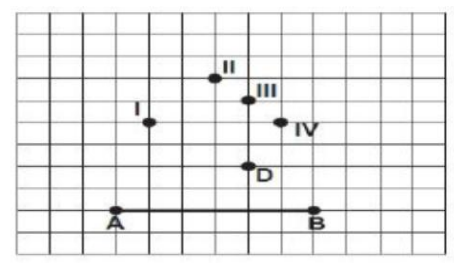

Yukarıda verilen sekilde A ve B noktaları haricinde hangi nokta $\mathrm{C}$ olarak seçilirse $\mathrm{ABC}$ üçgeninin $\mathrm{AB}$ kenarına ait kenarortayı $\mathrm{D}$ noktasından geçer? Açıklayınız?
1.

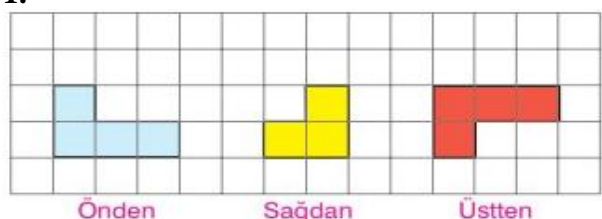

Yukarıdaki şekilde üç farklı yönden görünümü verilen eş küplerle oluşturulmuş yap1 aşağıdakilerden hangisi olabilir?
A)

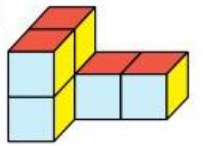

C)

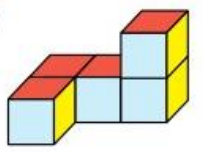

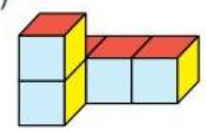

D)

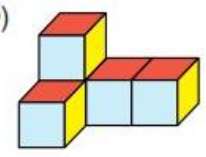

2. İki kenarı ve arasındaki açısı bilinen bir üçgeni inşa edebilmek için hangi araç gereçlere ihtiyaç vardır? Açıklayınız.

1.

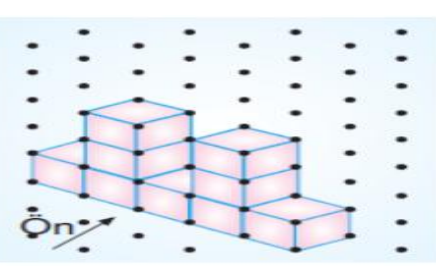

Yukarıda verilen şeklin önden, sağdan, soldan ve yukarıdan görünümlerini çiziniz.

1. Bir $A B C$ çeşitkenar üçgeninde $B$ ve $C$ merkezli, BC yarıçaplı çemberlerin kesim noktalarını birleştiren doğrunun inşası sizce üçgenin hangi elemanını çizer? Çizerek yorumlayını.
1. Herhangi bir doğru parçasının orta noktasını, GeoGebra yazılımının orta nokta ikonunu kullanmadan nasıl belirlersiniz? Yapınız.

2. Kenarları tamsayı ve çevresi $72 \mathrm{~cm}$ olan kaç tane ikizkenar üçgen çizebilirsiniz? 
Tablo 2'den görüldüğü gibi ders imecesi öncesinde kurulan problemlerden üçünün (\%75) bilme ve sadece birinin (\%25) anlamlandırma düzeyinde olduğu görülmektedir. Ders imecesi sonrasında kurulan problemlere bakıldığında ise ikisinin (\%40) bilme, birinin (\%20) uygulama ve ikisinin (\%40) anlamlandırma düzeyinde olduğu görülmektedir. Böylece ders imecesi çalışmaları sayesinde B2 öğretmeninin uygulama ve anlamlandırma düzeyinde kurduğu problemlerin sayısında artış olduğu belirlenmiştir. Üstelik B2, ders imecesi çalışmaları öncesinde uygulama seviyesinde hiç problem kurmamıştı. B2 öğretmenine yönelik araştırmacının tutmuş olduğu gözlem notu bu süreci aşağıdaki gibi özetlemektedir.

B2 öğretmeni uygulama seviyesinde hiç problem kuramad. Bilme seviyesinde kurulan problemlerde daha çok "Sizce hangi araç gereçlerle bu problemler çözülebilir?, Hangisini kullanırsak daha kolay çizeriz?," gibi sorularla ögrencilerin doğru cevaba ulaşmalarını sağladı̆̆ını gördüm. Bu esnada öğretmen ile görüşmem sürecinde B2 ögrretmenin şu ifadeleri, geometrik inşa sürecinde hangi araç gereçleri kullandiğını göstermekte idi. "Geometrik inşa sürecinde aklıma ilk gelen araç gereçleri kullandırmaya çalışırım. Bu araç gereçler de pergel, cetvel ve iletkidir."

Araştırmacının gözlem notunda da görüldüğü gibi B2 öğretmeni, ders imecesi çalışmaları öncesinde bilme seviyesinde daha çok problemler kurmuş ve geometrik inşa sürecinde ilk aklına gelen araç gereçlerin pergel, cetvel ve iletki olduğunu söylemiştir. B2 öğretmeninin, ders imecesi çalışmaları sonrasında daha fazla araç gereç kullanmaları yönünde öğrencilerine yönlendirmelerde bulunduğu tespit edilmiştir. Özellikle ders imecesi öncesinde dinamik yazılım kullanılmasını istemeyen B2 öğretmeninin, ders imecesi çalışmaları sonrasında GeoGebra yazılımının kullanılması gereken problem sorduğu Tablo 2'den görülmektedir. Öğretmen GeoGebra yazılımının kullanılmasını istediği anlamlandırmaya ait bu problemde, yazılımın özelliklerinden olan ve bu problem için direk sonuca ulaştıran orta 
nokta ikonunu öğrencilerinden kullanmamalarını istemiştir. Bu sayede problem, öğrenciler için anlamlandırma seviyesinde olmuştur. Bu problemin GeoGebra ekranındaki çözümü aslında şu şekildedir.

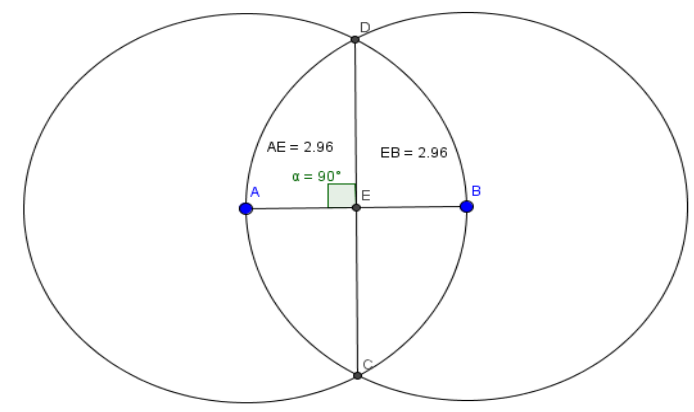

Şekil 2. GeoGebra yazılımı ile orta nokta ikonu kullanılmadan bir doğru parçasının orta noktasının inşa edilmesi.

B3 Öğretmeninin Kurduğu Problemlere Ders İmecesi Çalışmalarının Etkisi

Benzer şekilde B3 öğretmeninin ders imecesi çalışmaları öncesi ve sonrasında geometrik inşaya yönelik kurmuş olduğu problemler de aşağıdaki tablodaki gibidir. 
Tablo 3

B3 ögretmeninin kurmuş olduğu problemler

Ders İmecesi Öncesi Kurulan Problemler

1. Murat tek bir $\mathrm{ABC}$ üçgeni çizmek istemektedir. $\mathrm{ABC}$ üçgenini çizmek isteyen Murat, tek bir üçgeni aşağıdaki hangi bilgilerle çizemez? İnceleyerek Murat'a yardımcı olunuz.

$$
\text { I- }|A B|=6 b r,|A C|=10 \mathrm{br},|B C|=14 \mathrm{br}
$$

Bilme

$$
\text { II- } m(\hat{A})=40^{\circ}, m(\hat{B})=60^{\circ}, m(\hat{C})=80^{\circ}
$$

1. Murat tek bir $A B C$ üçgeni çizme istemektedir. ABC üçgenini çizmek isteyen Murat'a çizerek yardımc1 olunuz.

$$
\begin{aligned}
& \mathrm{I}-m(\hat{B})=50^{\circ}, m(\hat{C})=55^{\circ},|B C|=8 \mathrm{br} \\
& \mathrm{II}-m(\hat{A})=75^{\circ},|A B|=8 b r,|A C|=7 b r
\end{aligned}
$$

2. 8. sınıf öğrencisi Mehmet üçgenler konusuna çalışırken defterine aşağıdaki notları almıştır. I- İki köşeyi üst üste getirecek şekilde katlarsan, o köşelerin olduğu kenara ait yüksekliği bulursun. II- Eğer kâğıdın bir köşesinden katladığında, dik üçgen oluşuyorsa üçgenin o köşeden geçen yüksekliğini bulursun.

III- Bir köşeyi oluşturan kenarları üst üste gelecek şekilde katlarsan o köşedeki açının açırtayını bulursun.

Buna göre Mehmet'in tuttuğu yukarıdaki nottaki maddeleri üçgen şeklindeki bir kâğıtla yaparak doğruluklarını belirleyiniz.

3. İki açısı $45^{\circ}$ ve $65^{\circ}$ ve bu iki açı arasındaki kenar uzunluğu $4 \mathrm{~cm}$ olan üçgeni, cetvel ve iletki kullanarak çiziniz.
Ders İmecesi Sonrası Kurulan Problemler

1.

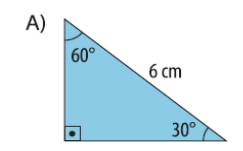

B)

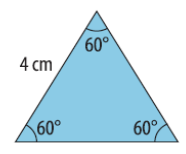

C)
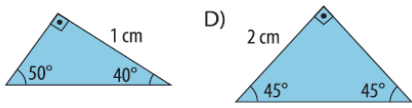

Yukarıda verilen üçgenlerden hangileri bir pergel ve cetvel kullanılarak çizilemez?

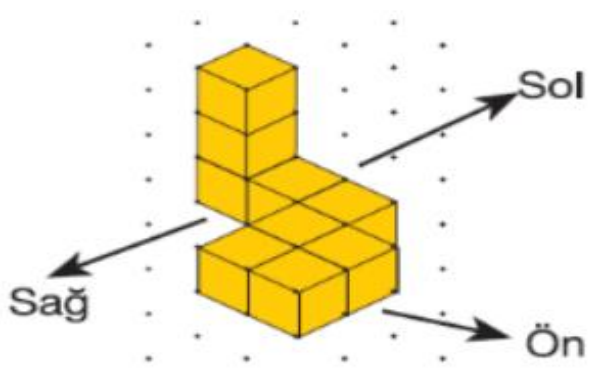

1. Yukarıda verilen şeklin önden, sağdan ve soldan görünümlerini çiziniz.

2. İki açısı $35^{\circ}$ ve $75^{\circ}$ ve bu iki açı arasındaki kenar uzunluğu $5 \mathrm{~cm}$ olan üçgeni, cetvel ve iletki kullanarak çiziniz.

1. Herhangi bir doğru üzerindeki noktadan doğruya dik bir doğruyu GeoGebra yazılımındaki dik doğru ikonunu kullanmadan oluşturunuz.

2. Herhangi bir doğruya dışındaki bir noktadan paralel doğruyu, GeoGebra yazılımında paralel doğru ikonunu kullanmadan nasıl yaparsınız? Çiziniz.

Ders imecesi çalışmaları öncesinde kurulan problemlere TIMSS 2007 seviyelerine göre Tablo 3'ten bakıldığında üç (\%75) problemin uygulama, bir (\%25) probleminde bilme basamağında olduğu görülmektedir. Sonrasında kurulan problemler incelendiğinde ise birinin 
(\%20) bilme, ikisinin (\%40) uygulama ve ikisinin (\%40) anlamlandırma düzeyinde olduğu belirlenmiştir.

Diğer taraftan B3 öğretmenine yönelik araştırmacının ders imecesi çalışmaları öncesi tutmuş olduğu gözlem notunda kurulan problemlerde hangi araç gereçlerin kullanıldığı ve bu süreçte öğrencilerin nasıl yönlendirildiği aşağıdaki gibi özetlenmiştir.

B3 ögretmeni de bilme ve uygulama seviyesinde problemler kurmuştu. Bu süreçte bilme seviyesinde bir, uygulama seviyesinde de üç adet problemler oluşturmuştu. Uygulama seviyesinde kâğıt katlama, pergel ve iletki kullanılmasını gerektiren problemler görülmekteydi. Bu süreçte B3 ögrretmeni ile yapılan görüşmede neden bu araç gereçleri kullanmak istediğini sorduğumda "Şu an aklıma bu araç gereçlerle problemler kurmak geldi" cevabını vermekle yetinmişti.

Ders imecesi çalışmalarının etkisi ile B3’ün anlamlandırma düzeyine yönelik problemler kurmaya başladığı görülmektedir. Bu duruma yönelik olarak B3 öğretmeninin ifadeleri aşağıdaki şekildedir.

A: İlk başta kurmuş olduğunuz problemler ile sonra kurmuş olduğunuz problemler arasında bir değişiklik var mı sizce?

B3: Var tabii ki hocam. İlk başta ögrrencileri daha fazla düşündürecek problemler sormadlk bence.

A: Sonrasinda neler değişti peki?

B3: Üstün yetenekli ögrencilere zaten anlamlandırma seviyesinde problemler bolca sorulmalı. Fakat biz, sizinle yaptı̆̆ımız çalışmalar öncesine kadar geometrik inşa problemleri üzerinde bu kadar durmuyorduk. Fakat çalışmalar sonrasında öğrencilere sorduğum problemler (anlamlandırma seviyesindeki problemler) neticesinde öğrencilerden iyi tepkiler aldım. 
Görüldüğü gibi B3 öğretmeni, üstün yetenekli öğrencilere yönelik daha fazla düşünme gerektiren geometrik inşa problemlerinin çözülmesi için anlamlandırma düzeyinde problemler kurmanın öneminden bahsetmiştir. Diğer taraftan B3 öğretmeninin ders imecesi çalışmaları sonrasında GeoGebra yazılımını kullanarak problemler kurmaya çalıştığı görülmektedir.

\section{Tartışma ve Sonuçlar}

BİLSEM matematik öğretmenlerinin geometrik inşaya yönelik olarak ders imecesi çalışmaları öncesinde daha çok bilme ve uygulama düzeyinde problemler kurdukları belirlenmiştir. Erduran ve Yeşildere (2010) de öğretmenlerin geometrik inşa çalışmalarında daha çok öğretmen merkezli bir yaklaşımı benimseyerek çizim aşamalarını derinlemesine incelemek yerine aşamaları sorgulatmadan ezbere bir anlayışla çizimleri gerçekleştirmeye çalıştıklarını belirtmiştir. Bunun sonucunda ise öğrenciler, geometrik inşa esnasında gerçekleştirdikleri işlemlerin alt yapısındaki kavramları tam olarak belirleyememektedirler (Hiebert \& Wearne, 1992). Ders imecesi çalışmaları sonrasında ise anlamlandırma düzeyinde problemlerin kurulduğu görülmüştür.

Araştırmada da görüldüğü gibi anlamlandırma düzeyine yönelik problemlerin kurulabilmesi için öğretmenlerin yaratıcı düşünmelerinin önemli olduğu söylenebilir. Anlamlandırma düzeyine yönelik olarak problemlerin kolay kurulmadığı veya oluşturulmadığı yapılan çalışmalarla ortaya konmuştur (Akkan, Çakıroğlu ve Güven, 2009; Korkmaz ve Gür, 2006; Silver \& Cai, 1996). Oysa araştırmada, ders imecesi çalışmaları sayesinde ilk önce öğretmenlere anlamlandırma düzeyine uygun problemlere örnekler sunularak bu tarz problemlerin önemi anlatılmış ve ardından öğretmenlerin uygulama esnasında da bu durumu tecrübe etmeleri sayesinde yukarıda bahsedilen olumsuz durumun önüne geçildiği söylenebilir.

Üstelik ders imecesi çalışmaları sonrası anlamlandırma düzeyinde sorulan problemlerin çoğunun GeoGebra yazılımı ile çözülmesi istenmiştir. Zaten yapılan çalışmalar 
GeoGebra yazılımının bireylerin üst düzey düşünmelerine firsat sağladığını göstermektedir (Antohe, 2009; Baydaş, 2010; Güven ve Karataş, 2003). Laborde, Kynigos, Hollebrands ve Strasser (2006) dinamik yazılımların kullanıldığı ortamlarda öğrenmenin kolay olmadığını ve bu ortamlarda öğrencilerin kendi geometri bilgilerini yeniden kurduklarını vurgulamıştır. Yine Baltaci ve Yildiz (2015) ve Sendova ve Grekovska (2005) bilgisayarlarla yapılan modellemeler ile öğrencilerin matematik bilgilerinin geliştiğini belirtmişlerdir. Ülkemizde de üstün yetenekli öğrencilerin eğitiminde bu tür yazılımların bir araç olarak kullanılması ile birlikte üstün yetenekli öğrencilerin hem düşünme süreçleri hem de bilgilerinin yeniden yapılandırılarak daha farklı öğrenmelerine imkân sağlanabilir.

Cherowitzo (2006) geometrik inşanın sadece çizim araçlarını kullanma becerilerinden ibaret olmadığını, öğrencilerin düşünme yeteneklerinin gelişmesinde de önemli olduğunu belirtmiş̧tir. Yapılan araştırmada da öğretmenler; üstün yetenekli öğrencilerin daha çok kazanımlara yönelik olarak verilen problemleri daha rahat çözdüklerini, bu problemleri çözerlerken araç gereç kullanmayı düşünmediklerini ve verilen problemlerde düşünmeden sonuca gitme eğilimi içerisinde olduklarını görmüşlerdir. Bu sebepten dolayı da BİLSEM matematik öğretmenleri, öğrencilerin daha fazla düşünmelerini sağlayacak şekilde sonraki uygulamalarda farklı problemler kurmaya çalışmışlardır. Ders imecesi çalışmaları sürecinde; anlamlandırmaya yönelik problemlerin kurulmasının gerekliliği, bu süreçte araç gereçlerin daha sık kullanılması ve araç gereçlerin sadece pergel, cetvel ve iletki ile sınırlı olmaması gibi ifadeler öğretmenler ile görüşüldüğünden bu durum ortaya çıkmış olabilir. Nitekim literatürde de ders imecesi çalışmaları sayesinde öğretmenlerin hem konuyla ilgili hem de pedagojik alan bilgilerinin arttı̆̆ı, öğrenciyi gözlemleme ve bilgiyi pratiğe dökme yeteneğinin gelişmesi gibi katkılarının olduğu bilinmektedir (Lewis, Perry \& Hurd, 2004; Lewis, Perry \& Murata).

$\mathrm{Bu}$ araştırmada öğretmenler, geometrik inşaya yönelik bilişsel seviye bakımından etkili bir problemin nasıl kurulacağını ders imecesi çalışmaları ile görebilmişlerdir. Bu durum 
Crawford, Chamblee ve Rowlett (1998)'in savındaki gibi öğretmenlerin farklı problem tiplerinin kurulmasının etkili yönlerini görebilmesi ile olmuştur. Böylece öğretmenler, genel olarak düşünüldüğünde ders imecesi çalışmaları sürecinde araştırmada incelenen durum bağlamında gelişim göstermişlerdir. Ders imecesi çalışmalarında konu ile ilgili olarak yapılan her tartışmada, eksik ve farklı yönlerin tespit edilerek düzeltilmeye çalışılması sonucunda öğretmenlerin bu şekilde gelişim göstermeleri beklenen bir durumdur. $\mathrm{Bu}$ nedenle öğretmenler kendi aralarında ders imecesi çalışmaları yaparak çeşitli konularda zorlukların aşılmasında pay sahibi olabilirler. Diğer taraftan üstün yetenekli öğrencilere yönelik hazırlanacak etkinlikler; üzerinde her öğrencinin fikir beyan edebileceği, merak uyandıran, keşfettiren, rutin problemlere benzemeyen ve işbirliğine uygunluk özelliklerine sahip olmalıdır (Baki, 2008; Reece \& Walker, 1997). O halde BİLSEM matematik öğretmenlerinin gelişimleri için benzer mesleki gelişim yaklaşımları kullanılmalıdır. Bu sayede üstün yetenekli öğrencilerimizi istenilen seviyede yetiştirebiliriz.

\section{Makalenin Bilimdeki Konumu (Yeri)}

Matematik ve Fen Bilimleri Bölümü / Matematik Eğitimi Anabilim Dalı Makalenin Bilimdeki Özgünlüğü

Literatürdeki geometrik yapılar üzerine yapılan çalışmalar göz önüne alındığında, öğretmenlerin derslerinde geometrik inşa sürecini kullanımının, inşa faaliyetleri ile öğrencilerin Van Hiele geometrik düşünce düzeyi arasındaki ilişkinin ve çeşitli inşa araçlarının (pusula, cetvel, dinamik geometri yazılımı vb.) geometrik inşa sürecinde kullanımının incelendiği görülmektedir. Türkiye'de ilkokuldan liseye kadar matematik ve geometri öğretim programlarında geometrik inşa faaliyetleri mevcuttur, fakat bu faaliyetler sürecinde çeşitli sorunlar ortaya çıkmaktadır. Ders imecesi ile ilgili çalışmalarda ise farklı ders imecesi uygulamalarının tanıtıldığı ve öğretmenlerin bir araya getirilerek görüşlerinin alındığ1 görülmektedir. Bu çalışmalar ile öğretmenlerin; öğretim tekniklerinin geliştiği 
belirlenmiştir. Fakat ülkemizde yapılan çalışmaların ise daha çok öğretmen adayları ile yürütüldüğü görülmektedir. Bu nedenle araştırmada, Bilim Sanat Merkezi matematik öğretmenlerinin kurdukları geometrik inşa problemlerine ders imecesi çalışmalarının etkisini incelemek amaçlanmıştır. Kurulan problemlerdeki gelişim, yukarıda bahsedilen TIMSS'in raporundaki bilişsel seviye çerçevesine göre irdelenmiştir. Bu bağlamda araştırmanın, yapılan çalışmalar incelendiğinde orijinal olacağ 1 ve literatüre önemli katkılar sağlayacağ söylenebilir. 


\section{Kaynakça}

Abu-Elwan, R. (1999). The development of mathematical problem posing skills for prospective middle school teachers. In A. Rogerson (Ed.), Proceedings of the International Conference on Mathematical Education into the 21st Century: Social Challenges, Issues and Approaches (Vol. 2, pp. 1-8). Cairo: Egypt.

Akkan, Y., Çakıroğlu, Ü., ve Güven, B. (2009). İlköğretim 6. ve 7. sınıf öğrencilerinin denklem oluşturma ve problem kurma yeterlilikleri. Mehmet Akif Ersoy Üniversitesi Ĕ̈itim Fakültesi Dergisi, 17, 41-55.

Aktepe, V., ve Aktepe, L. (2009). Fen ve teknoloji öğretiminde kullanılan öğretim yöntemlerine ilişkin öğrenci görüşleri: Kırşehir BİLSEM örneği. Ahi Evran Üniversitesi Kırşehir Eğitim Fakültesi Dergisi, 10 (1).

Antohe, V. (2009). Limits of educational soft "GeoGebra" in a critical constructive review annals. Computer Science Series. 7th Tome 1st Fasc, 2009, Tibiscus University of Timisoara, Romania.

Arıkan, E. E. (2014). Ortaokul öğrencilerinin matematik problemi çözme-kurma becerilerinin ve problem kurma ile ilgili metaforik düşüncelerinin incelenmesi (Yayınlanmamış doktora tezi). Yıldız Teknik Üniversitesi, İstanbul.

Baki, A. (2008). Kuramdan uygulamaya matematik ĕgitimi. Ankara: Harf Eğitim Yayınları.

Baki, M. (2012). Sınıf ögrretmeni adaylarının matematiği ögretme bilgilerinin gelişiminin incelenmesi: Bir ders imecesi (lesson study) çalışması (Yayınlanmamış doktora tezi). Karadeniz Teknik Üniversitesi, Trabzon.

Baki, A., Y1ldı, A., ve Baltaci, S. (2012). Mathematical thinking skills shown by gifted students while solving problems in a computer-aided environment. Energy Education Science and Technology Part B: Social and Educational Studies, Special Issue, 993995. 
Baltaci, S., ve Yildiz, A. (2015). GeoGebra 3D from the perspectives of elementary preservice mathematics teachers who are familiar with a number of software programs. Cypriot Journal of Educational Sciences, 10 (1), 12-17.

Baydaş, Ö. (2010). Öğretim elemanlarının ve ögretmen adaylarının görüşleri ışı̆̆ında matematik ögrretiminde GeoGebra kullanımı (Yayımlanmamış yüksek lisans tezi). Atatürk Üniversitesi Fen Bilimleri Enstitüsü, Erzurum.

Bütün, M. (2012). İlköğretim matematik öğretmeni adaylarının uygulanan zenginleştirilmiş program sürecinde matematiği öğretme bilgilerinin gelişimi (Yayınlanmamış Doktora Tezi). Karadeniz Teknik Üniversitesi, Trabzon.

Cherowitzo, B. (2006). Geometric constructions. [Online] 18 Ağustos 2016 tarihinde erişildi. URL http://www-math.ucdenver.edu/ wcherowi/courses/m3210/lecchap5.pdf

Crawford, A. R., Chamblee, G. E., \& Rowlett, R. J. (1998). Assessing concerns of algebra teachers during a curriculum reform: A constructivist approach. Journal of In-service Education, 24 (2), 317-327.

Erduran, A. ve Yeşildere, S. (2010). Geometrik yapıların inşasında pergel ve çizgecin kullanımı, İlköğretim Online, 9 (1), 331-345.

Fernandez, C.,\& Yoshida, M. (2004). Lesson study: A Japanese approach to improving mathematics teaching and learning. New Jersey: Lawrence Erlbaum Associates.

Gümüş, Ö. F. ve Umay, A. (2017). Problem çözme stratejileri öğretiminin ilköğretim matematik öğretmen adaylarının kavramsal/işlemsel çözüm tercihlerine ve problem çözme performansına etkisi, İlköğretim Online, 16(2), 746-764.

Güner, P. ve Akyüz, D. (2017a). Öğretmen adaylarının ders imecesi (lesson study) kapsamında matematiksel fark etmelerinin niteliği. Ondokuz Mayıs Üniversitesi Ĕ̆itim Fakültesi Dergisi, 36 (1), 47-82. 
Güner, P. ve Akyüz, D. (2017b). Ders imecesi mesleki gelişim modeli: Öğretmen adaylarının fark etme becerilerinin incelenmesi. Ilkogretim Online, 16 (2). 428-452.

Güven, B. \& Karataş, İ. (2003). Dinamik geometri yazılımı cabri ile geometri öğrenme: Öğrenci Görüşleri, The Turkish Online Journal of Educational Technology (TOJET), 2(2). 1303-6521.

Hiebert, J., \& Wearne, D. (1992). Links between teaching and learning place value with understanding in first grade. Journal for Research in Mathematics Education, 23 (2), 98-122.

Inoue, N. (2011). Zen and the art of neriage: Facilitating consensus building in mathematics inquiry lessons through lesson study. Journal of Mathematical Teacher Education, 14, $5-23$.

Karakuş, F. (2014). İlköğretim matematik öğretmeni adaylarının geometrik inşa etkinliklerine yönelik görüşleri. Kuramsal Eğitim Bilim Dergisi, 7 (4), 408-435.

Korkmaz, E. ve Gür, H. (2006). Öğretmen adaylarının problem kurma becerilerinin belirlenmesi. Balıkesir Üniversitesi Fen Bilimleri Enstitüsü Dergisi, 8(1).64-74.

Kondratieva, M. (2013). Geometrical constructions in dynamic and interactive mathematics learning environment. Mevlana International Journal of Education, 3 (3), $50-63$.

Koshy, V. (2002). Teaching gifted children 4-7. David Fulton Publishers Ltd. London.

Kuzle, A. (2013). Patterns of metacognitive behavior during mathematics problem-solving in a dynamic geometry environment. International Electronic Journal of Mathematics Education, 8, 1.

Laborde, C., Kynigos, C., Hollebrands, K., \& Strasser, R. (2006). Teaching and learning geometry with technology. Handbook of research on the psychology of mathematics education: Past, present and future. (pp. 275-304). Rotterdam, The Netherlands: Sense Publishers. 
Lewis, C. (2002). Lesson study: A handbook of teacher-led instructional change. Philadelphia: Research for Better Schools.

Lewis, J.F. (1982). Bulldozers or chairs? Gifted students decribe their ideal teachers. Gifted Child Today, 23, 16-19.

Lewis, C., Perry, R., \& Hurd, J. (2004). A deeper look at lesson study. Educational Leadership, 61(5), 18-22.

Lewis, C., Perry, R., Hurd, J., \& O'Cannell, M. P. (2006). Lesson study comes of age in North America, 88, 273-281. Phi Delta Kappan.

Lewis, C., Perry, R., Friedkin, S., \& Roth, J. (2012). Improving teaching does improve teachers: Evidence from lesson study. Journal of Teacher Education, 63 (5), 368-375.

Lewis, C., Perry, R., \& Murata, A. (2014). How should research contribute to instructional improvement? The case of lesson study. Educational Researcher, 35(3), 3-14.

Lim-Teo, S. K. (1997). Compass constructions: a vehicle for promoting relational understanding and higher order thinking skills. The Mathematics Educator, 2(2), 138147.

Lowrie, T. (2002). Designing a framework for problem posing: Young children generating open-ended tasks. Contemporary Issues in Early Childhood, 3(3), 354-364.

Millî Eğitim Bakanlığı (MEB) (2013a). Ortaokul matematik dersi 5-8. sınıflar öğretim programı ve kılavuzu. Ankara: MEB Yayıları.

Millî Eğitim Bakanlığı (MEB) (2013b). Ortaöğretim matematik dersi 9-12. sinıflar öğretim programı ve kılavuzu. Ankara: MEB Yayınları.

Miles, M. B., \& Huberman, A. B. (1994). Qualitative data analysis (2and Ed.). Thousand Oaks, CA:Sage Publication, Inc. 
Mullis, I., Martin, M., \& Foy, P. (2008). TIMSS 2007 international mathematics report: Findings from IEA's international mathematics and science study at the fourth and eighth grades. Evaluation and Educational Policy, Boston College.

Murata, A. (2011). Conceptual overview of lesson study: Introduction. In L. Hart, A. Alston \& A. Murata (Eds.), Lesson study research and practice in mathematics education: Learning together. NY: Springer. 1-12.

Napitupulu, B. (2001). An exploration of students' understanding and Van Hiele levels of thinking on geometric constructions (Unpublished Master Thesis). Simon Fraser University, Canada.

National Council of Teachers of Mathematics (NCTM). (2000). Principles and standards for school mathematics. Reston VA: Author.

Nixon-Ponder, S. (2001). Using problem-posing dialogue in adult literacy education. Retrieved October 10, 2017 from http://literacy.kent.edu/Oasis/Pubs/0300-8.htm

OCG. (2005). The Ontario Curriculum Grades 1-8 Ministry of Education 2005 Mathematics. Retrieved from http://www.edu.gov.on.ca/eng/curriculum/elementary/math18curr.pdf

Pandiscio, E. A. (2002). Exploring the link between preservice teachers' conception of proof and the use of dynamic geometry software. School Science and Mathematics, 102 (5), 216-221.

Pelczer, I., \& Rodriguez, F. G. (2011). Creativity assessment in school settings through problem posing tasks. Mont. Math. Ent., 8 (1-2), 383-398.

Perrin, J. R. (2007). Problem posing at all levels in the calculus classroom. School Science and Mathematics, 107 (5), 182- 188.

Posamentier, A. S. (2000). Making geometry come alive: Student activities and teacher notes. Thousand Oaks, CA: Corwin Press. 
Reece, I., \& Walker, S. (1997). Teaching, training and learning: A practical guide. Sunderland: Business Education Publishers.

Saito, E., Harun, I., Kuboki, I., \& Tachibana, H. (2006). Indonesian lesson study in practice: Case study of Indonesian mathematics and science teacher education project. Journal of In-service Education. 32 (2), 171-184.

Sak, U. (2010). Üstün zekâlılar: Özellikleri tanılanmaları eğitimleri. Ankara: Maya Akademi Yayınevi.

Sarkar Arani, M. R., Keisuke, F., \& Lassegard, J. P. (2010). "Lesson Study” as professional culture in Japanese schools: An historical perspective on elementary classroom practices. Japan Review, 22, 171-200.

Sendova, E., \& Grekovska, S. (2005). Visual modeling as a motivation for studying mathematics and art. Educational Media International, 42(2), 173-180.

Senge, P., Cambron-McCabe, N., Lucas, T., Smith, B., Dutton, J., \& Kleiner, A. (2000). Schools that learn: A fifth discipline fieldbook for educators, parents, and everyone who cares about education. NY: Doubleday.

Silver, E., \& Cai, J. (1993). Mathematical problem solving and problem posing by middle school students. Paper presented at the Annual Meeting of the American Education Research Association, Atlanta.

Silver, E., A., \& Cai, J. (1996). An analysis of arithmetic problem posing by middle school. Journal For Research in Mathematics Education, 27, 521- 539.

Silver, E. A. (1994). On mathematical problem posing. For the learning of mathematics, 14 (1), 19-28.

Silver, E. A. (1995) The nature and use of open problems in mathematics education: Mathematical and pedagogical perspectives. International Reviews on Mathematical Education, 27, 67-72. 
Sisk, D. (1987). Creative teaching for gifted. McGraw-Hill Book Company. England.

Smart, J. R. (1993). Modern Geometries. Pacific Grove, Calif.: Brooks.

Stoyanova, E. (2005). Problem solving strategies used by years 8 and 9 students. Australian Mathematics Teacher, 61(3), 6-11.

Şahin, F. ve Şahin, D. (2013). Bilim ve sanat merkezinde çalışan öğretmenlerin tükenmişlik düzeyinin incelenmesi. Üstün Yetenekliler Eğitimi Araştırmaları Dergisi, 1 (2), 51-66.

Tertemiz, N., Doğan, A. ve Karakaş, H. (2017). Üstün yetenekli tanısı konan ve üstün yetenekli tanısı konmayan başarılı 4. sınıf öğrencilerinin rutin olmayan problem çözümlerinin incelenmesi. International Journal of Curriculum and Instructional Studies, 7 (13).

Ticha, M., \& Hospesova, A. (2009, January). Problem posing and development of pedagogical content knowledge in pre-service teacher training. Paper presented in CERME 6. Lyon, France.

Yıldırım, A. ve Şimşek, H. (2008). Sosyal bilimlerde nitel araştırma yöntemleri (6. baskı). Ankara: Seçkin Yayıncılık.

Yıldı, A. (2013). Ders imecesinin matematik öğretmenlerinin problem çözme ortamlarında öğrencilerinin üstbilişlerini harekete geçirmeye yönelik davranışlarına etkisi (Yayınlanmamış doktora tezi). Karadeniz Teknik Üniversitesi, Trabzon. 


\section{Summary}

Problem Statement: It can be said that the education given to the gifted students that will be one of the important actors in the development of the countries is becoming more crucial today. In this education process, the potential of the lesson study, which has become an important approach in the professional development of the teachers in our country in recent years, can be benefitted. Mathematics teaching and problem-solving should be considered together in contemporary education understanding. In the conducted studies, problem-solving and problem posing seem to be connected and supported by each other. Problem-posing has also been found to contribute to the education of gifted students. However, teachers should also pay attention to the cognitive levels of the problems they have established in these activities. Cognitive levels are expressed in the report of TIMSS in 2007 as knowledge, practice, and meaning. By determining which cognitive level the students are able to solve, they will be able to increase the success in mathematics and geometry by providing appropriate guidance to answer unsolved problem types. Especially in the process of geometric construction in the Euclidean geometry, the indications in these components can guide the educators in the process from the building of geometric structures to the dissolution.

Considering the studies on geometric structures in the literature, it is seen that the use of geometric construction process in the lessons of teachers, the relation between the building activities and the students' level of geometric thinking of Van Hiele and the use of various building tools (compass, ruler, dynamic geometry software, etc.) in the geometrical construction process are examined. In Turkey, there are geometric construction activities in mathematics and geometry teaching programs from elementary school to high school, but there are various problems during the process. In the studies related to the lesson work, it is seen that different course work practices are introduced and the views of the teachers are brought together. With these studies, the development of teaching techniques has been 
determined. However, studies conducted in our country are mostly conducted with pre-service teachers.

Purpose of the Study: This research was aimed to explore the effect of the lesson study practices conducted by mathematics teachers who teach gifted students to develop geometrical construction problems in terms of the cognitive levels.

Method(s): Having used a case study method, the research was carried out with three mathematics teachers teaching the gifted students. One of the teachers has been working with the gifted students for about ten years while the other two for eight years. On the other hand, all teachers can use basic GeoGebra software and prepare events. With two-lesson study cycle, this research employed observation notes, interviews and students' notes as data collection tools. Each of the interviews was recorded with digital voice recorder with the permission of the teachers. Observation notes were also held by all the teachers during the application. The data were analyzed through qualitative data analysis methods.

Findings and Discussions: Research results have revealed that Science Art Center mathematics teachers pose problems at the levels of recognition and applying before conducting lesson study practices. Only one teacher could address questions to the students at the level of elaborating. However, all teachers have begun to pose problems at the level of elaborating thanks to lesson study practices. This was made possible by the fact that teachers could see the effective aspects of lesson study practices and the existence of different problem types. Teachers in the process of lesson work studies; they found that gifted students solved problems related to objectives more easily and that they did not consider to use tools while solving these problems and tended to lead to the conclusion without thinking in given problems. Because of this reason, Science Art Center mathematics teachers tried to set up different problems in subsequent applications, so that students could think more. As a result, teachers could see how to problem posing that was effective in terms of cognitive level for 
geometric construction with lesson studies. For this reason, teachers might have a part in overcoming the difficulties in various subjects by carrying out the study lessons. Thus, similar professional development approaches should be used for the development of Science Art Center mathematics teachers to train gifted students in the desired level.

Keywords: Science Art Center mathematics teachers, problem posing, geometrical construction problems, lesson study 